\title{
Erratum to: Improvement of gamete quality by stimulating and feeding the endogenous antioxidant system: mechanisms, clinical results, insights on gene-environment interactions and the role of diet
}

\author{
Maurizio Dattilo $^{1}$ - Giuseppe D'Amato ${ }^{2} \cdot$ Ettore Caroppo $^{2} \cdot$ Yves Ménézo $^{3}$
}

Published online: 21 November 2016

(C) Springer Science+Business Media New York 2016

Erratum to: J Assist Reprod Genet (2016)

DOI 10.1007/s10815-016-0767-4

The original version of this article unfortunately contained a mistake. The first name and family name of Giuseppe D'Amato and Ettore Caroppo were inverted. The update is provided here as well.

The online version of the original article can be found at http://dx.doi. org/10.1007/s10815-016-0767-4.

Maurizio Dattilo

maurizio.dattilo@parthenogen.ch

Parthenogen, Via F. Pelli 1, Lugano 6900, Switzerland

2 ASL Bari, U.O. Fisiopatologia della Riproduzione Umana e PMA, Conversano, Ba, Italy

3 London Fertility Associates, 104 Harley Street, London, UK 